\title{
Pengaruh Media Video pada Kelas Ibu Hamil terhadap Pengetahuan Sikap dan Perilaku Pemilihan Penolong Persalinan
}

\author{
Kirana Candra Sari ${ }^{1}$ \\ ${ }^{1}$ Magister Kebidanan, Fakultas Kesehatan, Universitas Aisyiyah Yogyakarta \\ Corresponding author: Kirana Candra Sari (kirana.dewantara@gmail.com)
}

Received 16 August 2019; Accepted 20 August 2019; Published 5 September 2019

\begin{abstract}
Maternal mortality during labor is very closely related to less skilled helpers and inadequate tools. Therefore labor should be assisted by skilled health workers because paraji is not equipped with emergency handling skills. The use of videos in pregnant classes can increase the knowledge, attitudes and behaviors of mothers to deliver to health workers. The purpose of this study was to determine the effect of video media on the class of pregnant women on knowledge, attitudes and behaviors of delivery helper selection. The design of this study used quasiexperimental with a randomized subjects post test only control group design approach. The researcher used the random assignment sampling method. This research was conducted in November 2018 in the Padasuka Community Health Center area, Bandung City, Bandung City Health Office. The research subjects were primiparous and multi-trimester pregnant women who participated in the class program of pregnant women who fulfilled the inclusion and exclusion criteria. The number of samples was 35 people consisting of 17 in the control group and 18 in the treatment group. Data analysis using $\mathrm{T}$ test and chi square test.The results showed that there was an influence of video media on the class of pregnant women on the knowledge of pregnant women in the selection of birth attendants ( $\mathrm{p}$ value $<0.001$ ). There is the influence of video media on the class of pregnant women on the attitude of pregnant women in the selection of birth attendants ( $\mathrm{p}$ value $=$ 0.026). In the control group and the treatment group, all pregnant women chose health workers $(100 \%)$ in childbirth assistants. Pregnant women are advised when attending classes for pregnant women to come with family members, so that family members also get knowledge about the importance of labor in health workers.
\end{abstract}

Keywords: Video class of pregnant women, Birth attendants

Copyright @ 2019 Institut Ilmu Kesehatan STRADA Indonesia All rights reserved.

This is an open-acces article distributed under the terms of the Creative Commons Attribution-ShareAlike 4.0 International License. 


\section{PENDAHULUAN}

Angka Kematian Ibu (AKI) merupakan indicator kesehatan ibu dan anak. Angka ini juga dapat melihat adanya kesuskesan program Pemerintah tentang Sustainable Development Goals (SDGs). Pembuatan SDGs berujuan untuk melanjutkan program Millenium Development Goal's (MDGS) yang belum tercapai(Kementerian PPN, 2014). Target SDGs 2015-2030 yang diharapkan adalah dapat mengurangi kematian ibu hingga 70 per 100.000 kelahiran hidup, target kematian neonates menjadi 12 per 1000 kelahiran hidup dan dan kematian balita menjadi 25 per 1000 kelahiran hidup. (Profil Kesehatan Kementerian Kesehatan, 2017).

Laporan Dinas Kesehatan Provinsi Jawa Barat tahun (2016), kematian ibu sebanyak 799 orang, (84,78/100.000 KH) dengan proporsi kematian pada ibu hamil 227 orang (20,09/100.000) pada ibu bersalin 202 orang $(21,43 / 100.000 \mathrm{KH})$ dan pada ibu nifas 380 orang $(40,32 / 100.000$ $\mathrm{KH}$ ). Penyebab AKI di Jawa Barat adalah perdarahan, hipertensi dan lain-lain (infeksi, partus lama, abortus dan pertolongan persalinan bukan oleh tenaga kesehatan. Pada umumnya kematian ibu terjadi pada saat melahirkan $(60,87 \%)$ waktu nifas $(30,43 \%)$ dan waktu kehamilan $(8,7 \%)$.

Kematian Ibu berhubungan erat dengan penolong persalinan. Cakupan persalinan oleh tenaga keseharan merupakan gambaran dari tingkat kesadaran masyarakat tetang pencegahan komplikasi persalinan. Berdasarkan laporan Dinas Kesehatan Jawa Barat tahun (2016) sebanyak 97,3\% persalinan yang ditolong oleh tenaga kesehatan. Cakupan ini meningkat bila dibandingkan tahun 2008 yang hanya 73,34\%. Namun demikian di Kota Bandung cakupan persalinan oleh tenaga kesehatan hanya 94,32\% dan di Puskesmas Padasuka Hanya 90,62\%. Dengan demikian hal tersebut masih menjadi masalah di Wilayah Kerja Puskesmas Padasuka.

Persalinan yang aman sebaiknya ditolong oleh tenaga kesehatan yang terampil. Tenaga kesehatan yang professional dapat memberikan pertolongan persalinan yang aman, serta mampu melakukan penanganan kegawatdaruratan pada ibu bersalinan(Saifudin, 2014). Dari hasil studi pendahuluan yang telah dilakukan, di kota Bandung selama tahun 2015, di Puskesmas Padasuka tercatat 2 kematian ibu dan di tahun 2016 juga terdapat 2 kematian ibu. (Laporan KIA Puskesmas Padasuka, 2016).

Menurut penelitian yang dilakukan oleh Yenita (2012) tentang kepercayaan di Sumatera Barat yang masih berlaku di masyarakat berhubungan terhadap pemilihan penolong persalinan. Masyarakat yang belum terpapar pengetahuan tentang pentingnya persalinan aman di tenaga kesehatan umumnya akan memilih bersalin di dukun melakukan penelitian. Sedangkan menurut Kristi et.al (2012) factor social ekonomi pada keluarga berhubungan dengan akses ibu hamil mendapatkan pelayanan kesehatan dan kualitas layanan, yang akan berpengaruh terhadap pemilihan tenaga penolong persalinan. Hal ini disebabkan akses layanan kesehatan akan memberikan pelayanan standard berupa informasi pentingnya persalinan di tenaga kesehatan sehingga akan meningkatkan pengetahuan, sikap dan perilaku ibu dalam memilih penolong persalinan.

Menurut Huang Kun et.al (2012) tentang upaya mengruangi kematian pada ibu dan bayi di daerah pedesaan di Cina. Pada penelitian ini membahas tentang perlunya peningkatan pengetahuan ibu tentang faktor resiko yang timbul selama masa kehamilan, persalinan dan nifas. Hal ini bisa dipengaruhi oleh beberapa faktor seperti dari pengetahuan, sikap dan perilaku ibu.

Menurut Depkes RI tahun 2009 salah satu pendekatan yang dilakukan adalah dengan kelas ibu hamil. Kelas ibu hamil dapat menjadi sarana edukasi bagi ibu hamil, di dalam kelas ibu hamil juga membahas buku Kesehatan Ibu dan Anak (KIA) terutama tentang perawatan kehamilan, tanda bahaya kehamilan, dan persiapan persalinan di tenaga kesehatan. Penjelasan buku KIA ini biasanya dilakukan di kelas kelas ibu hamil. Hal ini sebagai persiapan ibu menjalani proses kehamilan, persalinan, nifas, perawatan bayi baru lahir, bayi dan balita. Sayangnya penggunaan buku KIA tidak selalu dibawa dan hanya digunakan pada saat kelas ibu hamil atau kunjungan saja karena takut hilang, sehingga perlu alternative lain untuk meningkatkan pengetahuan ibu dalam pemilihan penolong persalinan di tenaga kesehatan.

Penggunaan video merupakan salah satu bentuk media pembelajaran yang dapat digunakan sebagai strategi untuk menarik minat belajar.penggunaan video dapat juga disebut audiovisual. Media audiovisual dapat meningkatkan kemampuan belajar melalui pengindraan mata dan telinga 
sehingga informasi dapat diterima lebih banyak. Media video juga dapat diperbanyak, diulangi pemutaran videonya bila belum jelas sehingga dapat meningkatkan pengetahuan, sikap dan perilaku. (Azwar, 2012). Kelas ibu hamil dengan menggunakan video, responden akan lebih tertarik untuk melihat, responden akan lebih mengingat materi yang disampaikan, dan dapat diulang - ulang setiap saat oleh responden di rumah jika diperlukan.

Diharapkan dengan adanya inovasi penggunaan media video pada kelas ibu hamil dapat mempengaruhi pengetahuan, sikap dan perilaku ibu hamil dalam memilih penolong persalinan.penelitian ini bertujuan untuk mengetahui pengaruh media video pada kelas ibu hamil terhadap pengetahuan, sikap dan perilaku pemilihan penolong persalinan.

\section{METODE}

Desain penelitian ini menggunakan quasi-experimental dengan pendekatan randomized subjects post test only control group design. Peneliti mengggunakan metode pengambilan sampel random assignment sampling. Penelitian ini dilaksanakan pada bulan November 2018 di wilayah Puskesmas Padasuka Kota Bandung Dinas Kesehatan Kota Bandung. Subjek penelitian adalah ibu hamil primipara dan multipara trimester III yang mengikuti program kelas ibu hamil yang memenuhi kriteria inklusi dan eksklusi. Jumlah sampel adalah 35 orang yang terdiri dari 17 pada kelompok kontrol dan 18 pada kelompok perlakuan. Kelompok intervensi mendapatkan intervensi pendidikan ibu hamil menggunakan video, sedangkan pada kelompok kontrol menggunakan pendidikan menggunakan buku KIA standar. Post test dilakukan setelah di berikan intervensi kelas ibu hamil sebanyak satu kali pertemuan Variabel yang diteliti pada penelitian ini adalah umur, pendidikan, status ekonomi, pengetahuan, sikap dan perilaku pemilihan tempat persalinan. Materi kelas ibu hamil terdiri dari Kehamilan, perubahan tubuh saat hamil, keluhan umum saat hamil dan cara mengatasinya, gizi termasuk pemberian $\mathrm{FE}$, tablet tambah darah untuk penanggulangan anemia. kesiapan psikologis, hubungan suami istri selama kehamilan, tanda-tanda kehamilan dan perencanaan persalinan dan pencegahan komplikasi. Entri data dan analisis statistik dilakukan dengan menggunakan Paket Statistik (SPSS). Data dianalisis menggunakan frekuensi uji T test dan uji chi square . Penelitian ini telah lulus uji etik di Universitas Aisyiyah Yogyakarta.

\section{HASIL}

Penelitian ini dilakukan di puskesmas Padasuka yang terletak di Kota Bandung dengan akreditasi Madya. Kelurahan Padasuka termasuk kedalam wilayah kecamatan cibeunying kidul bersama dengan 5 kelurahan lain, dengan puskesmas pasir payung sebangai wilayah binaan, memiliki jumlah RW 87 dan RT 559. Wilayah Padasuka memiliki penduduk yang sangat beragam baik dari segi ekonomi, tingkat pendidikan, asal daerah, agama, adat budaya, dan masih banyak lagi. Kepadatan penduduk merata dengan jumlah penduduk 102.293 jiwa.

Tabel 1 Karakteristik subjek Penelitian

\begin{tabular}{|c|c|c|c|c|c|c|}
\hline \multirow{3}{*}{ Variabel } & \multicolumn{4}{|c|}{ Kelompok } & \multirow[t]{3}{*}{ Total } & \multirow{3}{*}{$\begin{array}{c}\mathbf{p} \\
\text { Value }\end{array}$} \\
\hline & \multicolumn{2}{|c|}{ Control } & \multicolumn{2}{|c|}{ Perlakuan } & & \\
\hline & $\mathbf{N}$ & $\%$ & $\mathbf{n}$ & $\%$ & & \\
\hline \multicolumn{7}{|l|}{ Umur } \\
\hline$<20$ atau $>35$ tahun & 3 & 17,6 & 4 & 23,5 & 7 & \multirow[t]{2}{*}{1,000} \\
\hline 20-35 tahun & 14 & 82,4 & 13 & 76,5 & 27 & \\
\hline \multicolumn{7}{|l|}{ Pendidikan } \\
\hline Rendah & 10 & 58,8 & 4 & 23,5 & 14 & \multirow[t]{2}{*}{0,081} \\
\hline Tinggi & 7 & 41,2 & 13 & 76,5 & 20 & \\
\hline \multicolumn{7}{|l|}{ Status Ekonomi } \\
\hline$<$ UMK & 10 & 58,8 & 8 & 47,1 & 18 & \multirow{3}{*}{0,731} \\
\hline >UMK & 7 & 41,2 & 9 & 52,9 & 16 & \\
\hline Total & 17 & 100 & 17 & 100 & & \\
\hline
\end{tabular}


Berdasarkan table 1 didapatkan karakteristik pada kedua kelompok. Pada umur responden, sebagian besar kelompok control adalah berumur 20-35 tahun $(82,4 \%)$, demikian juga pada kelompok perlakuan, sebagian besar merupakan umur 20-35 tahun (76,8\%). Pada pendidikan, kelompok control sebagian besar berpendidikan rendah (58,8\%), sedangkan kelompok perlakuan sebagian besar berpendidikan tinggi $(76,2 \%)$. Pada status ekonomi, kelmpok control sebagian besar $<$ UMK, sedangkan pada kelompok perlakuan sebagian besar >UMK (52,9\%). Hasil uji statististik pada kedua kelompok didapatkan nilai karakteristik umur $(\mathrm{p}=1,000)$, pendidikan $(\mathrm{p}=0,081)$ dan status ekonomi $(\mathrm{p}=0,731)$, yang merupakan $\mathrm{p}>0,05$. Hal ini menunjukkan tidak ada hubungan bermakna karakteristik pada kelompok control dan perlakuan, sehingga kedua kelompok setara dan dapat dibandingkan.

Tabel 2 Analisis Bivariat hubungan karakteristik responden dengan pengetahuan ibu hamil dalam pemilihan penolong persalinan

\begin{tabular}{|c|c|c|c|c|c|c|c|}
\hline \multirow[t]{3}{*}{ Variabel } & \multicolumn{4}{|c|}{ Pengetahuan } & \multirow[t]{3}{*}{ Total } & \multirow{3}{*}{$\begin{array}{c}P \\
\text { value }\end{array}$} & \multirow[t]{3}{*}{ OR (CI95\%) } \\
\hline & \multicolumn{2}{|c|}{ Cukup } & \multicolumn{2}{|c|}{ Baik } & & & \\
\hline & $\mathbf{N}$ & $\%$ & $\mathbf{n}$ & $\%$ & & & \\
\hline \multicolumn{8}{|l|}{ Umur } \\
\hline$<20$ atau $>35$ tahun & 2 & 28,6 & 5 & 71,4 & 7 & \multirow[t]{2}{*}{0,672} & 0,500 \\
\hline 20-35 tahun & 12 & 44,4 & 15 & 55,6 & 27 & & $(0,082-3,046-2,320)$ \\
\hline \multicolumn{8}{|l|}{ Pendidikan } \\
\hline Rendah & 9 & 64,3 & 5 & 35,7 & 14 & \multirow[t]{2}{*}{0,035} & 5,400 \\
\hline Tinggi & 5 & 25,0 & 15 & 75,0 & 20 & & $(1,217-23,956)$ \\
\hline \multicolumn{8}{|l|}{ Status Ekonomi } \\
\hline$<$ UMK & 7 & 38,9 & 11 & 61,1 & 18 & \multirow{3}{*}{1,000} & \multirow[t]{3}{*}{$0,818(0,208-3216)$} \\
\hline >UMK & 7 & 41,2 & 9 & 58,8 & 16 & & \\
\hline Total & 14 & & 20 & & 34 & & \\
\hline
\end{tabular}

Pada tabel 2 dijelaskan hubungan karakteristik responden dengan pengetahuan ibu hamil dalam pemilihan penolong persalinan. Pada variabel umur, tidak ada hubungan umur dengan pengetahuan ibu hamil dalam pemilihan penolong persalinan ( $\mathrm{p}$ value $=0,672 ; \mathrm{OR}=0,500(0,082$ $3,046-2,320)$ ). Pada variabel pendidikan, ada hubungan pendidikan dengan pengetahuan ibu hamil dalam pemilihan penolong persalinan ( $\mathrm{p}$ value $=0,035 ; \mathrm{OR}=5,400(1,217-23,956)$. Pada variabel ekonomi, tidak ada hubungan ekonomi dengan pengetahuan ibu hamil dalam pemilihan penolong persalinan $(\mathrm{p}$ value $=1,000 ; \mathrm{OR}=0,818(0,208-3216)$.

Tabel 3 Analisis Bivariat hubungan karakteristik responden dengan sikap ibu hamil dalam pemilihan penolong persalinan

\begin{tabular}{|c|c|c|c|c|c|c|c|}
\hline \multirow[t]{3}{*}{ Variabel } & \multicolumn{4}{|c|}{ Sikap } & \multirow[t]{3}{*}{ Total } & \multirow{3}{*}{$\begin{array}{c}P \\
\text { value }\end{array}$} & \multirow[t]{3}{*}{ OR (CI95\%) } \\
\hline & \multicolumn{2}{|c|}{ Cukup } & \multicolumn{2}{|c|}{ Baik } & & & \\
\hline & $\mathbf{N}$ & $\%$ & $\mathbf{n}$ & $\%$ & & & \\
\hline \multicolumn{8}{|l|}{ Umur } \\
\hline$<20$ atau $>35$ tahun & 3 & 42,9 & 4 & 57,1 & 7 & 0,681 & $0,600(0,112-3,214)$ \\
\hline $20-35$ tahun & 15 & 55,6 & 12 & 44,4 & 27 & & \\
\hline \multicolumn{8}{|l|}{ Pendidikan } \\
\hline Rendah & 10 & 71,4 & 4 & 28,6 & 14 & 0,092 & $3,750(0,867-16,220)$ \\
\hline Tinggi & 8 & 40,0 & 12 & 60,0 & 20 & & \\
\hline \multicolumn{8}{|l|}{ Status Ekonomi } \\
\hline$<\mathrm{UMK}$ & 9 & 50,0 & 9 & 50,0 & 18 & 0,744 & $0,778(0,201-3,008)$ \\
\hline$>\mathrm{UMK}$ & 9 & 56,3 & 7 & 43,8 & 16 & & \\
\hline Total & 18 & & 16 & & 34 & & \\
\hline
\end{tabular}


Pada tabel 3 dijelaskan hubungan karakteristik responden dengan sikap ibu hamil dalam pemilihan penolong persalinan. Pada variabel umur, tidak ada hubungan umur dengan sikap ibu hamil dalam pemilihan penolong persalinan ( $\mathrm{p}$ value $=0,681 ; \mathrm{OR}=0,600(0,112-3,214)$. Pada variabel pendidikan, tidak ada hubungan pendidikan dengan sikap ibu hamil dalam pemilihan penolong persalinan ( $\mathrm{p}$ value $=0,092 ; \mathrm{OR}=3,750(0,867-16,220)$. Pada variabel ekonomi, tidak ada hubungan ekonomi dengan pengetahuan ibu hamil dalam pemilihan penolong persalinan $(\mathrm{p}$ value $=0,744 ; \mathrm{OR}=0,778(0,201-3,008))$.

Tabel 4 Analisis Bivariat hubungan karakteristik responden dengan perilaku ibu hamil dalam pemilihan penolong persalinan

\begin{tabular}{|c|c|c|c|c|c|c|c|}
\hline \multirow[t]{3}{*}{ Variabel } & \multicolumn{4}{|c|}{ Perilaku } & \multirow[t]{3}{*}{ Total } & \multirow{3}{*}{$\begin{array}{c}P \\
\text { value }\end{array}$} & \multirow[t]{3}{*}{ OR (CI95\%)* } \\
\hline & \multicolumn{2}{|c|}{ Nakes } & \multicolumn{2}{|c|}{ Non nakes } & & & \\
\hline & $\mathbf{n}$ & $\%$ & $\mathbf{n}$ & $\%$ & & & \\
\hline \multicolumn{8}{|l|}{ Umur } \\
\hline$<20$ atau $>35$ tahun & 7 & 100 & 0 & 0 & 7 & - & - \\
\hline 20-35 tahun & 28 & 100 & 0 & 0 & 28 & & \\
\hline \multicolumn{8}{|l|}{ Pendidikan } \\
\hline Rendah & 15 & 100 & 0 & 0 & 15 & - & - \\
\hline Tinggi & 20 & 100 & & & 20 & & \\
\hline Status Ekonomi & & & 0 & 0 & & & \\
\hline$<\mathrm{UMK}$ & 18 & 100 & 0 & 0 & 18 & - & - \\
\hline$>\mathrm{UMK}$ & 17 & 100 & 0 & 0 & 17 & & \\
\hline Total & 35 & 100 & & & 35 & & \\
\hline
\end{tabular}

Pada tabel 4 dijelaskan hubungan karakteristik responden dengan perilaku ibu hamil dalam pemilihan penolong persalinan. Hasil penelitian menujukkan seluruh responden memilih penolong persalinan di tenaga kesehatan $(100 \%)$. Pada variabel perilaku pemilihan tempat persalinan pada tenaga kesehatan 0\%, sehingga kedua kolom kosong dan menyebabkan tidak dapat dianalisis statistic (pvalue/OR tidak dapat dihitung).

Tabel 5 Pengaruh media video pada kelas ibu hamil terhadap pengetahuan ibu hamil dalam pemilihan penolong persalinan

\begin{tabular}{lllllll}
\hline Kelompok & Mean (SD) & Median & $\begin{array}{l}\text { Min- } \\
\text { maks }\end{array}$ & $\begin{array}{l}\text { Mean } \\
\text { Difference }\end{array}$ & t & P value \\
\hline Kontrol & $60,0(12,57)$ & 64,0 & $40-80$ & 12,94 & 5,510 & $<0,001$ \\
Perlakuan & $80,0(8,12)$ & 64,0 & $64-96$ & & & \\
\hline
\end{tabular}

Pada tabel 5 didapatkan hasil pengetahuan pada kedua kelompok. Nilai rata-rata pengetahuan pada kelompok perlakuan $80,0(8,12)$ yang lebih tinggi bila dibandingkan dengan kelompok control $60,0(12,57)$ pada akhir penelitian. Hasil uji statistic didapatkan nilai $p$ value $<0,001$, yang berarti bahwa ada pengaruh media video pada kelas ibu hamil terhadap pengetahuan ibu hamil dalam pemilihan penolong persalinan. 
Tabel 6 Pengaruh media video pada kelas ibu hamil terhadap sikap ibu hamil dalam pemilihan penolong persalinan

\begin{tabular}{llllllll}
\hline Kelompok & Mean (SD) & Median & $\begin{array}{l}\text { Min } \\
\text { maks }\end{array}$ & $\begin{array}{l}\text { Mean } \\
\text { Difference }\end{array}$ & T & P value \\
\hline Kontrol & $64,12(21,45)$ & 65,0 & $25-90$ & 20,0 & 2,242 & $<0,032$ \\
Perlakuan & $77,06(10,31)$ & 75,0 & $65-90$ & & & \\
\hline
\end{tabular}

Pada tabel 6 didapatkan data sikap ibu hamil pada kedua kelompok. Nilai rata-rata sikap ibu hamil pada kelompok perlakuan 77,06(10,31) yang lebih tinggi dari kelompok kontrol 64,12(21,45). Hasil uji statistik menunjukkan $p$ value $=0,032$. Hal ini berarti bahwa terdapat pengaruh media video pada kelas ibu hamil terhadap sikap ibu hamil dalam pemilihan penolong persalinan.

Tabel 7 Pengaruh media video pada kelas ibu hamil terhadap perilaku ibu hamil dalam pemilihan penolong persalinan

\begin{tabular}{|c|c|c|c|c|c|c|c|c|}
\hline \multirow{3}{*}{$\begin{array}{l}\text { Penolong } \\
\text { Persalinan }\end{array}$} & \multicolumn{4}{|c|}{ Kelompok } & \multirow[t]{3}{*}{ Total } & \multirow[t]{3}{*}{$\%$} & \multirow[t]{3}{*}{$P$ value } & \multirow[t]{3}{*}{$\mathbf{R R}$} \\
\hline & \multicolumn{2}{|c|}{ kontrol } & \multicolumn{2}{|c|}{ Perlakuan } & & & & \\
\hline & $\mathbf{n}$ & $\%$ & $\mathbf{n}$ & $\%$ & & & & \\
\hline Non Nakes & 0 & 0 & 0 & 0 & 0 & 0 & - & - \\
\hline Nakes & 17 & 100 & 18 & 100 & & & & \\
\hline Total & 17 & 100 & 18 & 100 & & & & \\
\hline
\end{tabular}

Pada tabel 7 menunjukkan pemilihan penolong persalinan pada kedua kelompok. Pada kelompok control maupun kelompok perlakuan, seluruh ibu hamil memilih tenaga kesehatan (100\%) pada penolong persalinan. Berdasarkan hal tersebut maka tidak dapat dianalisis secara statistik untuk melihat pengaruh media video pada kelas ibu hamil terhadap pemilihan penolong persalinan.

\section{PEMBAHASAN}

Pengaruh media video pada kelas ibu hamil terhadap Pengetahuan ibu hamil dalam pemilihan penolong persalinan

Pada penelitian ini ada pengaruh media video pada kelas ibu hamil terhadap pengetahuan ibu hamil dalam pemilihan penolong persalinan. Pengetahuan adalah merupakan hasil "tahu" dan ini terjadi setelah orang melakukan penginderaan terhadap suatu obyek tertentu. Penginderaan terjadi melalui panca indera manusia yaitu : indera penglihatan, pendengaran, penciuman, rasa dan raba. Sebagian besar pengetahuan manusia diperoleh melalui mata dan telinga (Notoadmojo, 2010).

Pengetahuan memang sangat penting, sesuai dengan ajaran kita sebagai umat Islam dalam ayat berikut ini :Wahai orang-orang yang beriman, apabila dikatakan kepadamu, berilah kelapangan di dalam majelis-majelis, maka lapangkanlah. Niscaya Allah Swt. akan memberi kelapangan untukmu. Apabila dikatakan, berdirilah kamu, maka berdirilah. Niscaya Allah Swt akan mengangkat (derajat) orang-orang yang beriman di antaramu dan orang-orang yang diberi ilmu beberapa derajat. Allah Swt maha teliti apa yang kamu kerjakan." (Surah al-Mujadalah/58: $11)$.

Kelas ibu hamil merupakan sarana yang memfasilitasi ibu hamil untuk berlajar bersama dalam bentuk kelompok-kelompok ibu hamil yang difasilitasi oleh bidan dan kader kesehatan. Pada kelas ibu hamil, ibu mendapatkan informasi yang menambah pengetahuan, sikap dan perilaku ibu untuk dapat bersalin di tenaga kesehatan Dengan diadakannya kelas ibu hamil diharapkan dapat meningkatkan pengetahuan, merubah sikap dan perilaku ibu agar dapat memahami mengenai persiapan dalam menghadapi persalinan (Depkes RI, 2011). 
Media audiovisual adalah jenis media yang mengandung unsur suara dan gambar yang bisa kita lihat, misalnya rekaman video (Sanjaya, 2007). Penggunaan video dalam kelas ibu hamil dapat membantu ibu lebih memahami materi tentang kehamilan, hal ini karena ibu hamil memanfaatkan lebih banyak indera dibandingkan dengan hanya buku KIA (Arsyad, 2007).

Hasil penelitian ini rata-rata pengetahuan pada kelompok perlakuan $80,7(8,37)$ yang lebih tinggi bila dibandingkan dengan kelompok control 60,0(12,5) pada akhir penelitian. Pada kelompok perlakuan rata-rata 80,7 merupakan kategori ibu hamil memiliki pengetahuan yang baik. Sedangkan pada kelompok control rata-rata 60 menunjukkan ibu hamil memiliki pengetahuan yang cukup terhadap penolong persalinan.

Menurut penelitian Novadela dan Spriatiningsih (2013) menjelaskan ada perbedaan signifikan antara pengetahuan ibu sebelum dan setelah mengikuti kelas ibu. Hasil penelitian ini menjelaskan bahwa jika kelas ibu ini dilakukan dengan baik dapat meningkatkan pengetahuan seseorang. Hal ini dikarenakan selama kelas ibu hamil, ibu dapat melakukan diskusi dengan sesame ibu hamil, berbagi pengalaman, mendapatkan informasi tentang kehamilan, persalinan dan tempat persalinan.

Sejalan dengan penelitian Saban (2017) tentang penyuluhan penggunaan video dibadningkan dengan media leaflet pada siswi SMAN 2 Ngaglik Sleman, media video audiovisual lebih efektif dalam meningkatkan pengetahuan kesehatan dibandingkan menggunakan media flip chart. Subjek penelitian yang diberikan pendidikan kesehatan menggunakan video akan lebih mudah memahami informasi karena mengaktifkan lebih banyak indra dibandingkan hanya menggunakan flipchart. Informasi dengan video ini akan menambah pemahaman ibu sehingga pengetahuan ibu dapat lebih baik.

Pada penelitian ini, kelas ibu hamil pada kedua kelompok sama-sama dapat meningkatkan pengetahuan. Namun demikian kelompok yang diberikan pendidikan video memiliki pengetahuan yang lebih baik. Hal ini karena Media audiovisual merupakan media perantara yang materi dan penyerapannya melalui pandangan dan pendengaran sehingga membangun kondisi yang dapat membuat ibu hamil mampu memperoleh pengetahuan dan keterampilan. Materi dalam video dikemas berupa efek gambar yang bergerak dengan alur cerita yang menarik serta suara sehingga memberikan gambaran yang lebih nyata.

\section{Pengaruh media video pada kelas ibu hamil terhadap sikap ibu hamil dalam pemilihan penolong persalinan.}

Pada penelitian ini menunjukkan sikap kelompok perlakuan lebih tinggi dibandingkan kelompok kontrol secara bermakna. Menurut La Pierre dalam (Azwar, 2005) sikap merupakan respon yang timbul dari rangsangan social yang sudah dikondisikan. Kelas ibu hamil bertujuan untuk terjadinya interaksi dan berbagi pengalaman antar peserta dan antar petugas dengan peserta tentang materi dan topik yang sudah diberikan serta meningkatkan pemahaman, sikap dan perilaku ibu hamil terhadap kesiapan dalam menghadapi persalinan termasuk upaya perencanaan persiapan persalinan (Depkes, 2011).

Menurut penelitian Nurhapipa dan Sepriana (2015) ada hubungan antara sikap ibu dengan penolong persalinan. Hal ini menunjukkan bahwa adanya respon yang tidak setuju dari ibu terhadap penolong persalinan oleh dukun bayi tidak dilakukan pelatihan, maka kemungkinan besar ia akan memilih dukun bayi untuk penolong persalinan. Hasil penelitian ini nilai rata-rata sikap ibu hamil pada kelompok perlakuan 72,2 (7,5) yang lebih tinggi dari kelompok kontrol 64,1 $(21,4)$. Pada kelompok perlakuan rata-rata 72,5 merupakan kategori ibu hamil memiliki pengetahuan yang cukup. Sedangkan pada kelompok kontrol rata-rata 64 menunjukkan ibu hamil memiliki pengetahuan yang cukup terhadap penolong persalinan.

Menurut penelitian Liska (2018) kelas ibu hamil dapat meningkatkan sikap ibu dalam menentukan pemilihan penolong persalinan. penelitian ini menunjukkan rata-rata untuk sikap ibu ibu hamil dalam pemilihan penolong persalinan (pretest) sebesar 84,65 dan postest 88,89 yang artinya terdapat pengaruh pelaksanaan kelas ibu hamil terhadap sikap pemilihan penolong persalinan dengan nilai signifikan. 
Media video mempunyai banyak kelebihan diantaranya dapat diulang - ulang bila perlu menambah kejelasan, pesan yang disampaikan cepat dan mudah diingat, video dapat mendorong dan meningkatkan motivasi untuk tetap melihat. Pemberian kelas ibu hamil dengan menggunakan video, responden akan memiliki sikap lebih tertarik terhadap materi yang disampaikan dan dapat diulang - ulang setiap saat oleh responden di rumah (Azwar,2011).

Hal ini sejalan dengan penelitian Zakaria (2017) yang menjelaskan bahwa ada pengaruh signifikan penggunaan media audiovisual terhadap sikap ibu hamil tentang inisiasi menyusui dini. Ibu hamil yang mendapatkan pendidikan menggunakan audiovisual memiliki peningkatan sikap yang lebih signifikan dibandingkan dengan yang hanya menggunakan media visual saja. Hal ini karena pada media audiovisual juga lebih menarik perhatian, menghemat waktu dan dapat diputar berulang-ulang.

Pada penelitian ini, menunjukkan kelas ibu hamil pada kedua kelompok sama-sama dapat meningkatkan sikap ibu hamil. Namun demikian kelompok yang diberikan pendidikan video memiliki sikap yang lebih baik.

\section{Pengaruh media video pada kelas ibu hamil terhadap perilaku ibu hamil dalam pemilihan penolong persalinan}

Perilaku manusia merupakan aktivitas atau semua kegiatan yang dapat diobservasi dan nilai langsung oleh orang lain (Notoatmodjo, 2010). Menurut Arroba (2008) factor yang mempengaruhi orang mengambil keputusan diantarnya adalah informasi, pengetahuan, tingkat pendidikan, sikap, coping (dalam hal ini dapat berupa pengalaman hidup yang terkait dengan pengalaman dan kebudayaan (Arroba, 2008).

Menurut Syaifuddin (2014) bahwa tenaga yang dapat memberikan pertolongan selama persalinan dapat dibedakan menjadi dua yaitu tenaga kesehatan yakni mereka yang mendapatkan pendidikan formal seperti : dokter spesialis, dokter umum, bidan dan perawat, sedangkan yang bukan tenaga kesehatan yaitu dukun bayi, baik yang terlatih maupun yang tidak terlatih.

Pada penelitian ini analisis perilaku pemilihan pertolongan persalinan tidak dapat dilakukan. Hal ini karena baik pada kelompok perlakuan maupun kelompok control seluruh ibu hamil memilih tenaga kesehatan (100\%) pada penolong persalinan. Secara teori pemilihan penolong persalinan adalah suatu penetapan pilihan penolong persalinan terhadap persalinan ibu yang melahirkan (Gaskin, 2003). Meskipun hasil didapatkan 100\% namun praktiknya pertolongan persalinan di Puskesmas pada suka masih kurang dari target.

Berdasarkan Riskesdas (2018), cakupan pertolongan oleh tenaga kesehatan di Indonesia sebanyak 93,1\%. Menurut Badan Pusat Statistik Jawa Barat Cakupan (2018) mencapai 97,3\%. Di Kota Bandung (2018) adalah 94,32\%. Sedangkan di Puskesmas Padasuka Hanya 90,62\%. Berdasarkan data diatas, cakupan persalinan di Puskesmas Padasuka jauh dibawah cakupan Nasional, Provinsi dan Kota sehingga perlu mendapat perhatian.

Penyebab ternyadinya perbedaan data penelitian (100\% memilih di tenaga kesehatan ) dengan cakupan yang ada di Puskesmas $(90,62 \%)$ dapat disebabkan oleh beberapa factor. Menurut Teori Green dan Kreuter (1991) factor yang mempengaruhi perilaku seseorang adalah factor predisposing (pengetahuan, sikap dan komunikasi), factor pemungkin ( fasilitas, pelayanan kesehatan dan sumber daya manusia), dan factor penguat (sikap dan perilaku petugas kesehatan serta peraturan persalinan di tenaga kesehatan).

Menurut Geen fakktor predisposing perbengaruh terhadap pengetahuan dan sikap karena, faktor utama yang menyebabkan $100 \%$ ibu memilih bersalin di tenaga kesehatan adalah karena subjek penelitian adalah ibu yang bersedia ikut dalam kelas ibu hamil, baik kelompok perlakuan maupun kelompok control. Program kelas ibu hamil ini memiliki beberapa keuntungan yaitu meningkatkan pengetahuan ketrampilan dan pengetahuan melalui evaluasi pelaksanaan kelas ibu hamil. Ibu hamil lebih paham dan terjadi perubahan sikap dan perilaku ibu hamil terhadap kesiapan menghadapi persalinan yang mencakup upaya perencanaan persiapan persalinan dan pencegahan komplikasi serta mengetahui tanda bahaya persalinan dan tanda-tanda persalinan. Program ini dilakukan untuk mendapatkan persalinan yang aman oleh tenaga kesehatan yang meliputi kegiatan menentukan tempat bersalin, menentukan penolong persalinan, menginformasikan riwayat 
kehamilan, tanda-tanda persalinan, penentuan pendamping persalinan, dan pengambilan keputusan jika terjadi rujukan (Depkes, 2011).

Menurut penelitian Rochayah (2012) didapatkan kelas ibu hamil berpengaruh terhadap pemilihan penolong persalinan. Kelas ibu hamil dapat meningkatkan pengetahuan secara signifikan 3 kali untuk meningkatkan persalinan di tenaga kesehatan. Selain itu ibu hamil yang rutin hadir di kelas ibu hamil akan cenderung memilih bersalin di tenaga kesehatan. Oleh sebab itu, baik pada kelompok perlakuan maupun kelompok control seluruhnya memilih bersalin di tenaga kesehatan karena ibu telah mengikuti kelas ibu hamil.

Sesuai dengan penelitian Linarsih (2012) menjelaskan bahwa ada pengaruh kelas ibu hamil dalam peningkatan kesehatan ibu dan anak. Hasil menunjukkan bahwa ibu yang aktif dalam kegiatan kelas ibu hamil dapat meningkatkan pengetahuan dan keterampilan. Dengan demikian kelas ibu hamil merupakan program dalam menekan morbiditas dan mortalitas ibu dan bayi.

Akses informasi yang didapatkan oleh ibu hamil selama kehamilan dapat mempengaruhi ibu mengambil keputusan dalam menentukan penolong persalinan. Bidan memberikan kelas ibu hamil menggunakan media sesuai dengan yang biasanya di sampaikan oleh bidan, menggunakan lembar balik. Strategi ini dilakukan pemerintah untuk mempermudah pemberian pelayanan kepada ibu hamil. Pemberian media video dapat meningkatkan pengetahuan dan sikap untuk lebih meyakinkan penentuan penolong persalinan oleh tenaga kesehatan. Namun demikian, pemberian lembar balik juga dapat memberikan informasi terkait penolong persalinan oleh tenaga kesehatan. Selain itu terdapat beberapa faktor lain yang mempengaruhi dalam pengambilan keputusan persalinan.

Hasil penelitian ini sesuai dengan penelitian Mentari (2013) yang menyatakan bahwa tidak ada perbedaan tingkat kecemasan ibu hamil yang menggunakan edukasi audiovisual dengan video dibandingkan dengan metode standard. Hal ini karena banyak factor lain yang tidak dapat dikontrol oleh peneliti pada saat penelitian, seperti factor budaya, dukungan keluarga, pekerjaan, dan ekonomi.

Menurut penelitian Hutapea (2012) menunjukan distribusi responden yang mengikuti kelas ibu hamil memilih tenaga kesehatan sebagai penolong persalinan lebih tinggi bila dibandingkan dengan yang tidak mengikuti kelas ibu hamil. Hasil uji statistik menyatakan ada hubungan yang signifikan antara keikutsertaan kelas ibu hamil dengan pemilihan penolong persalinan. Responden yang mengikuti kelas ibu hamil memiliki peluang lima kali memilih tenaga kesehatan sebagai penolong persalinan dibandingkan dengan yang tidak.

Menurut penelitian Alhidayati (2016) menyatakan bahwa faktor yang mempengaruhi keputusan ibu memilih penolong persalinan sangat berkaitan dengan pengetahuan, sikap, sosial budaya, akses ke pelayanan kesehatan, dukungan keluarga. Ibu hamil yang memiliki pengetahuan yang baik akan cenderung memilih penolong persalinan dari tenaga kesehatan. Namun masyarakat Indonesia juga masih ada yang memegang teguh budaya persalinan dengan bantuan dukun bayi. Hal ini sulit dihilangkan karena tradisi yang sudah berjalan lama dan turun-temurun. Akses fasilitas kesehatan mempengaruhi ibu dalam mengambil keputusan, ibu hamil yang jauh dapat kesulitan menjangkau fasilitas kesehatan dan mempengaruhi penolong persalinan. Perilaku pemilihan penolong persalinan oleh ibu sangat tergantung pada suami/dukungan keluarganya, bisa dilihat pada keluarga yang suaminya/ keluarganya tidak mendukung untuk ditolong oleh tenaga kesehatan, maka ibu tersebut akan mempertimbangkan pilihannya untuk bersalin ke tenaga kesehatan atau pada dukun bayi.

Hal ini sesuai dengan penelitian Lail dkk (2018) yang menjelaskan bahwa ibu hamil yang memiliki pengetahuan, asuransi kesehatan, dukungan keluarga dan dukungan tenaga kesehatan lebih memilih bersalin di tenaga kesehatan. Akses tenaga kesehatan dalam pelayanan dan pembelrian kelas ibu hamil dapat menambah informasi ibu hamil. Factor informasi dapat meningkatkan pengetahuan. Namun demikian dukungan keluarga dan asuransi kesehatan juga berpengaruh. Ibu hamil yang tidak didukung keluarga dan tidak memiliki asuransi akhirnya bersalin di tenaga non kesehatan, meskipun awalnya memilih di tenaga kesehatan.

Penelitian ini memiliki keterbatasan diantaranya adalah waktu pengambilan post test, pemilihan subjek penelitian dan pengendalian factor lain. Waktu pengambilan post test dilakukan setelah kelas ibu hamil, sehingga perilaku pemilihan penolong persalinan belum dapat diobservasi 
pada saat persalinan. Selain itu ibu yang menjadi responden adalah ibu yang mengikuti kelas ibu hamil yang sebelumnya sudah terpapar kegiatan kelas ibu hamil, sehingga ibu cenderung sudah terpapar oleh tenaga kesehatan. Pengendalian factor lain seperti ibu yang tidak mengikuti kelas ibu hamil, dukungan keluarga, lingkungan dan budaya tidak dilakukan pada penelitian ini karena keterbatasan waktu, tempat dan biaya penelitian.

Menurut penelitian Safitri (2017) menunjukkan bahwa factor lingkungan (dukungan suami, dukungan ibu/ibu mertua) menjadi factor yang berpengaruh terhadap pemilihan tempat persalinan. Hal ini keluarga merupakan lingkungan terdekat ibu untuk menentukan pilihan melahirkan. Maka dari itu dukungan keluarga menjadi alasan memilih tempat persalinan. Keluarga yang biasa terpapar oleh dukun bersalin (paraji), umumnya tidak aktif berkunjung ke tenaga kesehatan apalagi mengikuti program asuhan kehamilan di tenaga kesehatan (kelas hamil) oleh sebab itu biasanya sejak awal ibu sudah ingin melahirkan dibantu oleh dukun. Suami atau keluarga tidak akan melarang keputusan dengan alasan tidak ingin memaksakan kehendak istri yang ingin bersalin di non tenaga kesehatan.

Menurut Fauzia (2014) Faktor lain seperti promosi persalinan di tenaga kesehatan juga berpengaruh terhadap pemilihan tempat persalinan di tenaga kesehatan. Dalam penelitian ini dijelaskan bahwa dengan adanya promosi kesehatan dapat membujuk ibu untuk bersalin di tenaga ksehatan. Hal ini karena ibu hamil selalu diingatkan manfaat pentingnya bersalin di tenaga kesehatan melalui media promosi kesehatan yang mudah diakses.

\section{KESIMPULAN}

Berdasarkan hasil penelitian dan pembahasan dari penelitian ini, maka peneliti menarik kesimpulan bahwa pada kelompok control maupun perlakuan, seluruh subjek telah menentukan pilihan untuk bersalin di tenaga kesehatan karena kedua kelompok mendapatkan edukasi dari kelas ibu hamil. Namun demikian, media video kelas ibu hamil lebih meningkatkan pengetahuan dan sikap tentang pemilihan tempat persalinan dibandingkan media standard yang ada. Sehingga media video pada kelas ibu hamil lebih efektif meningkatkan pengetahuan dan sikap ibu hamil dalam memilih penolong persalinan. Sehingga media video kelas ibu hamil yang dapat digunakan kapanpun ini juga dapat dimanfaatkan pada ibu hamil yang tidak mengikuti kelas ibu hamil pada saat kunjungan kehamilan di Puskesmas. Bidan desa juga dapat memanfaatkan pada saat kunjungan rumah ibu hamil untuk menambah pengetahuan dan sikap ibu tentang pemilihan tempat persalinan di Tenaga Kesehatan

\section{REFERENSI}

Alhidayati, \& Asmuliyanti. (2016). Perilaku Ibu Dalam Memilih Tenaga Penolong Persalinan Di Wilayah Kerja Puskesmas Tembilahan Hulu Tahun 2016. Jurnal Kesehatan Reproduksi. Vol Desember. No.3 hal 155162.

BPS Jawa Barat. (2018). Provinsi Jawa Barat Dalam Angkan 2018. Badan Pusat Statistik. https://jabar.bps.go.id diakses 09 April 2019.

Dinkes Kota Bandung. (2018). Tabel Profil Kesehatan Kota Bandung 2017. https://dinkes.bandung.go.id/dashboard.php?page=profildinas diakses 09 April 2019.

Fauzia, R. (2014). Faktor-Faktor Yang Berhubungan Dengan Keputuasan Pemilihan Tempat persalinan Pasien Poliklinik Kandungan Dan Kebidanan DI Rumah Sakit Ibu dan Anak Kemang Medical Care Tahun 2014. Skripsi. Program Studi Kesehatan masyarakat. Universitas Islam Negeri Syarif Hidayatullah Jakarta.

Hutapea, E. (2012). Faktor-Faktor Yang Berhubungan Dengan Pemilihan Penolong Persalinan Di Wilayah Kerja Puskesmas Cibungbulang Kecamatan Cibungbulang Kabupaten Bogor Jawa Barat Tahun 2012. Skripsi. Fakultas Kesehatan Masyarakat. Universitas Indonesia.

Kristi, Costa, A., D., Vishal, D., Mavalankar, V., \& Dileep. (2012). An evaluation of two large scale demand side financing programs for maternal health in India: the MATIND study protocol. 12-699. 
Linarsih. (2012). Pengaruh Kelas Ibu Hamil Terhadap Peningkatan Pengetahuan dan Keterampilan Ibu Hamil Mengenai Kesehatan Ibu dan Anak di Wilayah Puskesmas Sempor II Kabupaten Kebumen. Skripsi. Fakultas Kesehatan Masyarakat. Universitas Indonesia.

Liska, C., Ruhayati, R. (2018). Pengaruh Pelaksanaan Kelas Ibu Hamil Terhadap Pengetahuan Tentang Tanda-Tanda Bahaya Kehamilan Dan Sikap Dalam Pemilihan Penolong Persalinan Di Wilayah Kerja Uptd Yankes Pacet Kabupaten Bandung. Jurnal Ilmiah Indonesia. Vol. No.12 Hal 27-36.

Lail, N., H., Sufiawati, W. (2018). Pemilihan Tenaga Penolong Persalinan Di Desa Panancangan Kecamatan Cibadak Kabupaten Lebak Provinsi Banten Tahun 2017. Jurnal Akademi Keperawatan Husada Karya Jaya. Vol. 4 No. 01. Hal 21-40.

Mentari, Astuti, Iw., \& Kusmarjathi, Nk. (2013). Pengaruh Pemberian Audiovisual Antenatal Care Education Terhadap Tingkat Kecemasan Ibu Primigravida Untuk Menghadapi Persalinan. Program Studi Ilmu Keperawatan Fakultas Kedokteran Universitas Udayana.

Notoatmodjo, S. (2014). Ilmu Perilaku Kesehatan. Jakarta. Rineka Cipta.

Nurhapipa, \& Sepriana, Z. (2015). Faktor Yang Mempengaruhi Ibu Dalam Memilih Penolong Persalinan Di Puskesmas XIII Koto Kampar I. Jurnal Kesehatan Komunitas. Vo.2. no.^. Hal 1-6.

Riskesdas. (2018). Riset Kesehatan Dasar. Jakarta. Kementrian Kesehatan RI.

Rochayah. (2012). Hubungan Kelas Ibu Hamil Dengan Pemilihan Penolong Persalinan Di Wilayah Puskesmas Bruno Kabupaten Purworejo Tahun 2012. Skripsi. Fakultas Kesehatan Masyarakat. Universitas Indonesia.

Saban, S. (2017). Efektifitas Media Video Dan Leaflet Terhadap Pengetahuan Tentang Anemia Siswi Sman 2 Ngaglik Sleman. Universitas Aisyiyah Yogyakarta. Fakultas Ilmu Kesehatan. Skripsi.

Safitri, AAL. (2017). Alasan Pemilihan Penolong Persalinan di Non-Nakes Pada Ibu Melahirkan di Wilayah Kerja Puskesmas Pebayuran Kabupaten Bekasi Tahun 2016. Skripsi. Program Studi Kesehatan masyarakat. Universitas Islam Negeri Syarif Hidayatullah Jakarta.

Yenita, A., Shigeko, H., Porter, S., E. (2012). Rural Indonesia women's traditional beliefs about antenatal care doi: 10.1186/1756-0500-5-589.

Zakaria, F. (2017). Pengaruh Pendidikan Kesehatan Dengan Media Audiovisual Terhadap Pengetahuan Dan Sikap Ibu Tentang Inisiasi Menyusu Dini Di Kota Yogyakarta. Program Studi Magister Kebidanan. Universitas 'Aisyiyah Yogyakarta. 